\title{
Physicochemical/photophysical characterization and angiogenic properties of Curcuma longa essential oil
}

\author{
LILHIAN A. ARAÚJO' ${ }^{1}$, RAFAEL G.M. ARAÚJO², FLÁVIA O. GOMES ${ }^{2}$, SUSY R. \\ LEMES $^{1}$, LUCIANE M. ALMEIDA ${ }^{3}$, LAURO J.Q. MAIA ${ }^{4}$, PABLO J. GONÇALVES ${ }^{4}$, \\ FÁTIMA MRUÉ ${ }^{2}$, NELSON J. SILVA-JUNIOR ${ }^{2}$ and PAULO R. DE MELO-REIS ${ }^{2}$ \\ ${ }^{1}$ Universidade Federal de Goiás, Biotecnologia e Biodiversidade, Campus Samambaia, \\ ICB IV, Avenida Esperança, Setor Itatiaia, 74001-970 Goiânia, GO, Brasil \\ ${ }^{2}$ Pontifícia Universidade Católica de Goiás, Laboratório de Estudos Experimentais e \\ Biotecnológicos, Área V, Rua 232, 128, 74605-140 Goiânia, GO, Brasil \\ ${ }^{3}$ Universidade Estadual de Goiás, UnU-Ipameri, Rodovia GO-330, Km 241 Anel Viário, 75780-000 Ipameri, GO, Brasil \\ ${ }^{4}$ Instituto de Física, Universidade Federal de Goiás, Campus Samambaia, Avenida \\ Esperança, Setor Itatiaia, 74001-970 Goiânia, GO, Brasil
}

Manuscript received on September 3, 2015; accepted for publication on March 1, 2016

\begin{abstract}
This study analyzed the physicochemical and photophysical properties of essential oil of Curcuma longa and its angiogenic potential. The results showed that curcumin is the main fluorescent component present in the oil, although the amount is relatively small. The experimental chorioallantoic membrane model was used to evaluate angiogenic activity, showing a significant increase in the vascular network of Curcuma longa and positive control groups when compared to the neutral and inhibitor controls $(\mathrm{P}<0.05)$, but no significant difference was found between Curcuma longa essential oil and the positive control $(\mathrm{P}>0.05)$. Histological analysis showed extensive neovascularization, hyperemia and inflammation in the positive control group and Curcuma longa when compared to other controls $(\mathrm{P}<0.05)$, characteristic factors of the angiogenesis process. In conclusion, Curcuma longa oil showed considerable proangiogenic activity and could be a potential compound in medical applications.
\end{abstract}

Key words: angiogenic activity, curcumin, essential oil, physicochemical.

\section{INTRODUCTION}

In recent years the search for materials that stimulate the angiogenesis process has received considerable attention. In particular, biomaterials produced from natural rubber latex have shown biocompatibility as well as stimulating angiogenesis, cell adhesion and extracellular matrix formation (Floriano et al.

Correspondence to: Lilhian Alves de Araújo

E-mail: lilhianalves@gmail.com
2013, Mrue et al. 2004). Angiogenesis is a complex biological process that favors the formation of new blood vessels from preexisting vascular tissue by proliferation, migration, regulation and differentiation of vascular cells (Folkman 2003). From the point of view of medical applications, materials that induce angiogenesis are important for tissue engineering, to enhance cell proliferation or promote wound healing (Schulz et al. 2003, Shen and Falanga 2003). 
Medicinal herbs used in folk medicine have proven to be an important source of compounds with potential for development of a number of medications (Iwu et al. 1994, Phillipson 1994). The various plants used in folk medicine include different turmeric extracts (Curcuma longa L.). C. longa is a rhizome-bearing perennial herb from the Zingiberaceae family, which is native to Southern Asia and cultivated extensively throughout the warmer climates of the world (Mostajeran et al. 2014). In Brazil, C. longa, widely used as a spice, food preservative and coloring, is frequently confused with true saffron, a Mediterranean plant not cultivated in the country (Mata et al. 2004).

There are several data in the literature indicating a wide variety of pharmacological activities of $C$. longa, which exhibits anti-inflammatory, antihuman immunodeficiency virus, antibacterial, and antioxidant effects, as well as nematocidal activities (Araújo and Leon 2001, Jurenka 2009, Nasri et al. 2014). In particular, the essential oil extracted from the rhizome has been shown to possess anti-inflammatory activity, increasing bile flow and efficacy against bronchial asthma (Srimal 1997).

The aim of this study was to evaluate the potential of $C$. longa essential oil as a biomaterial to stimulate angiogenesis. Angiogenic potential was assessed in vivo through the chick embryo chorioallantoic membrane model (CAM). In order to obtain physicochemical and photophysical characterization of the essential oil, different techniques were employed, such as: Thermogravimetric analyses (TGA), Fourier transform infrared (FTIR), UV-Vis absorption and fluorescence spectroscopies.

\section{MATERIALS AND METHODS}

EXTRACTION OF SAFFRON ESSENTIAL OIL

Essential oil was extracted from $C$. longa rhizome powder using the hydrodistillation method with steam distillation. In order to avoid significant losses and minimize errors during the process, the operation took place in a closed circuit with the aid of a Clevenger apparatus (Santos et al. 2004). C. longa rhizome powder $(150 \mathrm{~g})$ was added to 500 $\mathrm{ml}$ of distilled water in a round-bottom glass flask. The powder was distilled for 180 minutes and the distillate separated into two phases, an aqueous phase at the bottom of the separator tube and an oil phase at the top. The oil was stored in a sterilized test tube under cooling and light, and identified.

PHYSICOCHEMICAL AND PHOTOPHYSICAL CHARACTERIZATION

FTIR spectra were recorded with a Vertex 70 Bruker spectrophotometer. The FTIR spectra were obtained in the attenuated total reflectance (ATR) mode, in the $400-4000 \mathrm{~cm}^{-1}$ range. TGA was carried out with a Shimadzu DTG 60/60H thermoanalyzer. Dynamic scans were conducted at a temperature range between 43 and $600^{\circ} \mathrm{C}$, at constant heating rates of $10^{\circ} \mathrm{C} \mathrm{min}^{-1}$, under air atmosphere with a flow of $50 \mathrm{mLmin}^{-1}$ using an alumina crucible. The weight of the material was $13.504 \mathrm{mg}$. UVVis absorption measurements were carried out with a Perkin Elmer Lambda $1050 \mathrm{UV} / \mathrm{Vis} /$ NIR spectrophotometer. Excitation, steady-state emission and spectra were recorded by a Horiba Jobin Yvon FluoroMax-3 spectrofluorometer. Time-resolved fluorescence was acquired using an apparatus based on the time correlated single photon counting (TCSPC) method. The excitation source was a titanium-sapphire laser (Tsunami 3950Spectra Physics), pumped by a second harmonic diode-pumped Nd:YVO laser (Millenia-Spectra Physics), with frequency doubled to $465 \mathrm{~nm}$ in an LBO crystal (GWN-23PL-Spectra Physics); additional details can be found in (Rodrigues et al. 2015, Sampaio et al. 2012).

ANGIOGENIC POTENTIAL / CAM ASSAY

The CAM model was used to evaluate angiogenic activity according to a previously described 
methodology (Melo- Reis et al. 2010, Ribatti et al. 2000). Sixty fertile chicken eggs (Gallus domesticus) of the Ross lineage were incubated at $37^{\circ} \mathrm{C}$ in a humidified atmosphere $(60-70 \%$ relative humidity). On the $5^{\text {th }}$ day of incubation, a circular hole was opened in the large end of the eggshell, the CAM membrane removed, and the eggs returned to the incubator. Filter paper disks were soaked in $5 \mu \mathrm{L}$ of the following solutions: 1. $C$. longa essential oil; 2. Regederm ${ }^{\circledR}$ - a commercial product from Pele Nova Biotecnologia prepared with Hevea brasiliensis latex (positive control); 3. water (neutral control); and 4. dexamethasone $4 \mathrm{mg} / \mathrm{ml}$ (inhibitor). After receiving the treatment solutions, the filters were placed on top of the growing CAM on day 13 of incubation under sterile conditions. The angiogenic response was evaluated 72 hours after incubation. CAMs were fixed in formaldehyde solution $(3.7 \%)$ for 10 minutes, cut with blunt curved scissors and kept in Petri dishes in the presence of formaldehyde solution. Analysis and quantification of a newly-formed vascular net were conducted through captured images. The area of each assay was determined using Gimp for Windows (version 2.0.5) and Image $J(\mathrm{NIH})$ imaging programs (version 1.28). The images were prepared so that saturation, light and contrast allowed better resolution of the blood vessels, which were quantified in each corresponding pixel (Parente et al. 2011). In order to analyze the angiogenic activity of $C$. longa essential oil, the treated and control groups were compared using one way analysis of variance (ANOVA) of ranks, followed by Tukey's test ( $\mathrm{n}=10$ membranes). $\mathrm{P}$ values of less than $0.05(\mathrm{P}<0.05)$ were considered significant.

Histology OF THE CAM BLOOD VESSELS

The CAM membranes fixed in formaldehyde solution $(3.7 \%)$ were processed, sealed in paraffin, sectioned with a Spencer micrometer at a thickness of $5 \mu \mathrm{m}$, marked by hematoxylin and eosin and examined by microscopy (Zeiss - Axioskop). Slides were examined by an experienced pathologist blinded to the treatment, and photographs were representative of five membranes per group. The following parameters were evaluated: the presence of inflammatory elements, hyperemia and neovascularization. The results were visually classified according to intensity, and the data were transformed into quantitative variables, assigning the following scores: absent (0), slight (1 to $25 \%$ ), moderate (26 to 50\%), and accentuated (over 51\%). The results were evaluated using the Kruskal-Wallis test with a significance level of $5 \%(\mathrm{P}<0.05)$.

\section{RESULTS AND DISCUSSION}

PHYSICOCHEMICAL AND PHOTOPHYSICAL CHARACTERIZATION

FTIR spectroscopy, an effective analytical tool for detecting functional groups and characterizing covalent bonding, has been employed to study biological systems and their processes (Gonçalves et al. 2006). Figure 1a shows the FTIR spectra of C. longa tumeric powder and essential oil extracted from C. longa. The FTIR spectra of C. longa obtained here is in agreement with the literature (Shameli et al. 2014). The FTIR results indicate that extraction of the essential oil from the rhizome causes a significant reduction in the strong broad bands between 3100 and $2900 \mathrm{~cm}^{-1}$, which are attributed to bonded hydroxyl $(-\mathrm{OH})$ or amine groups $(-\mathrm{NH})$ and aliphatic $\mathrm{C}-\mathrm{H}$ of $C$. longa tumeric powder extract. Moreover, a decline was observed in the 1157 and $1020 \mathrm{~cm}^{-1}$ bands attributed to $\mathrm{C}-\mathrm{O}$ (stretching vibrations of oligosaccharides) and C-4-OH (typical of disaccharides), respectively (Anastasaki et al. 2010, Mohanty and Sahoo 2010, Ordoudi et al. 2014, Shameli et al. 2014). This indicates that the extraction process produces the same components as those of the initial material, but there may be a polymerization process that increases oil chains. 

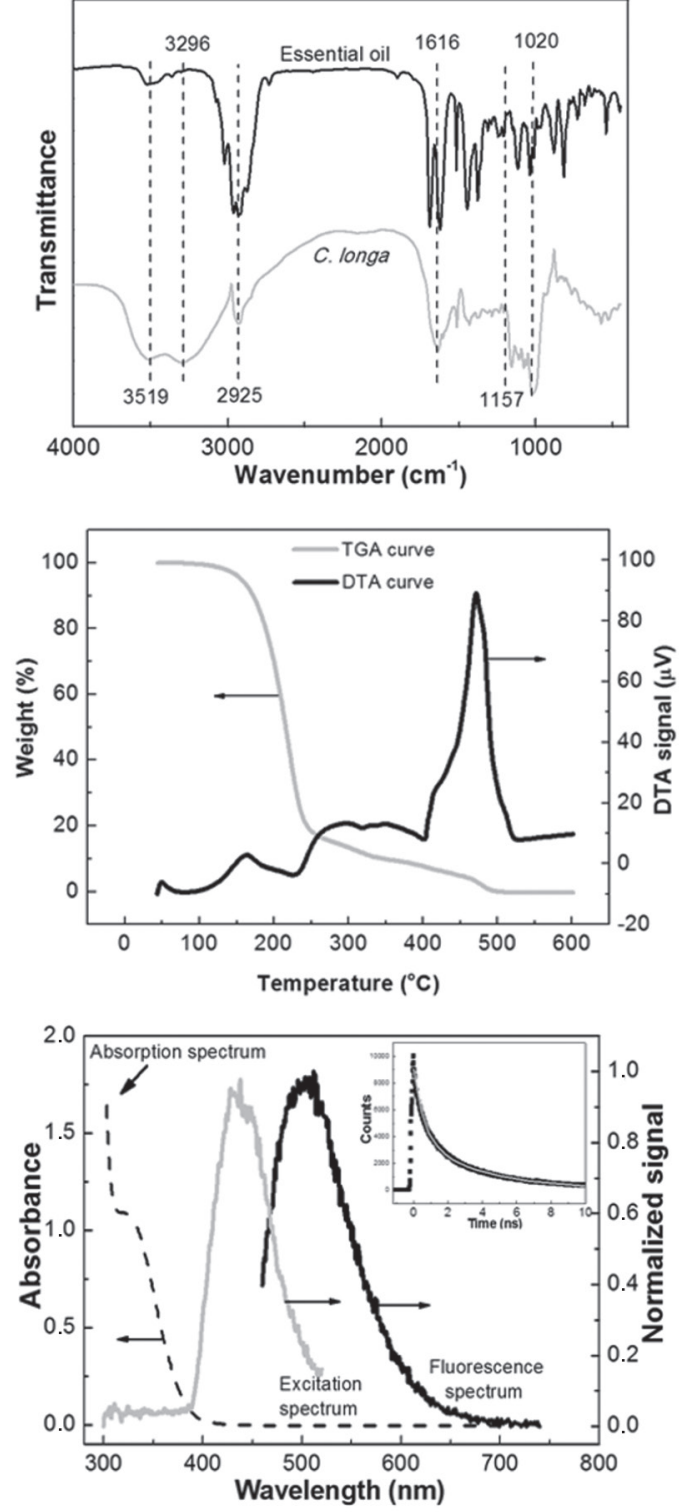

Figure 1 - (a) FTIR spectra of $C$. longa tumeric powder and essential oil extracted from C. longa, (b) TGA and DTA curves of essential oil, and (c ) UV-Vis absorption, normalized emission and normalized excitation spectra. The inset shows the time-resolved fluorescence of essential oil of C. longa.

Thermogravimetric analysis (TGA) makes it possible to study changes in the physical and chemical properties of materials as a function of increasing temperature (Figure 1b). The TGA curve shows high essential oil thermal stability up to $90^{\circ} \mathrm{C}$. In the $90-270^{\circ} \mathrm{C}$ range there is a significant loss of mass (around 84\%), possibly associated with two nearly overlapping endothermic processes shown on the DTA curve. These endothermic peaks are associated with evaporation of low molecular weight organic molecules. A loss of weight of around 9\% can be observed in the $270-408^{\circ} \mathrm{C}$ range, corresponding to a large exothermic band. In the 462 to $500^{\circ} \mathrm{C}$ range there is an intense exothermic peak at $472^{\circ} \mathrm{C}$, which may be associated with oxidation/combustion reactions of high molecular weight molecules formed during the extraction process. This result is in line with the enhancement of $\mathrm{C}-\mathrm{H}$ and $\mathrm{C}-\mathrm{C}$ vibrations observed in the FTIR results.

C. longa essential oil is a natural yellowishorange compound soluble in polar organic solvents. Thus, photophysical characterization is a valuable study to identify the chromophore and fluorophore compounds present in the sample. UVVis absorption and fluorescence emission spectra for essential oil diluted $(20 \mathrm{x})$ in DMSO are shown in Figure 1c. Intense absorption in the UV region can be observed, with a shoulder close to $322 \mathrm{~nm}$. A broad and structureless fluorescence band can be obtained with excitations between 400 and 480 $\mathrm{nm}$. The fluorescence spectra recorded at different wavelengths exhibit no wavelength dependence. The fluorescence decay curve was obtained using the time-correlated single photon counting method shown in the inset of Figure 1c. The oil was excited at $430 \mathrm{~nm}$ and the emission was collected at 505 $\mathrm{nm}$. Time-resolved fluorescence analysis shows a double-exponential fit with lifetimes of $0.5 \mathrm{~ns}$ (51\%) and $3.3 \mathrm{~ns}(47 \%)$.

Fluorescence excitation spectra indicate that the main fluorescent component absorbs from 400 to $500 \mathrm{~nm}$. Although essential oil of C. longa is a complex mixture of chemical compounds, the results obtained by excitation and fluorescence spectra suggest that curcumin is the main fluorescent component (Ghosh et al. 2011, Erez et al. 2014). The fact that the excitation spectra do not match the absorption spectra suggests that 
fluorescent resonance energy transfer (FRET) occurs from absorber compounds, absorbing in the $300-400 \mathrm{~nm}$ range, to fluorescent curcumin, a fluorescent acceptor compound that emits from 425 to $700 \mathrm{~nm}$. The FRET process, a physical phenomenon present in some biological systems, may take place when a donor compound in an electronically excited state transfers its excitation energy to a fluorescent acceptor compound, which, in turn, emits fluorescence (Lakowicz 2006).

The fact that the absorption band of curcumin is not observed in the UV-Vis spectra (Figure 3) leads us to believe that there is only a small amount of curcumin in the essential oil. This corroborates the literature, which generally shows that the major components of essential oil, accounting for around $80 \%$ of the total, are ar-turmerone, $\alpha$-turmerone and $\beta$-turmerone, while curcumin represents about 1\% (Péret-Almeida et al. 2008, Ferreira et al. 2013).

With respect to the time-resolved fluorescence measurements, the fast component observed may also be attributed to curcumin, which exhibits a fluorescence lifetime of dozens to hundreds of picoseconds (Erez et al. 2014). On the other hand, the long-lasting component could be attributed to residues or other compounds formed during the oil extraction process.

\section{ANGIOGENIC POTENTIAL - CAM ASSAY}

Angiogenesis is a process in which new capillaries sprout from preexisting vessels (Chen et al. 2011). Angiogenic drug research, an important area in modern biomedical science, involves primarily the search for plant-based compounds. More than $50 \%$ of all drugs in clinical use are of natural origin, which shows the importance of plants as a potential source of therapeutic agents (Majewska and Gendaszewska-Darmach 2011).

Figure 2a shows images of different CAMs obtained in the present study. As can be seen, more and thicker blood vessels were formed in two groups: $C$. longa essential oil and the positive control (Regederm $\left.{ }^{\circledR}\right)$, when compared with the neutral control (water) and the angiogenic inhibitor (Dexamethasone) groups. Moreover Fig. 2b shows the percentage of vascularization as measured by CAM image analysis. For C. longa essential oil the mean vascularization percentage was $46.4 \pm$ 4.6; for the positive control, $53.3 \pm 4.3$; for the neutral control, $32.5 \pm 3.3$ and for the angiogenic inhibitor, 12.3 \pm 2.0 . C. longa essential oil showed a significant increase in the vascular network formed, compared to the neutral control $(\mathrm{P}<0.05)$ and the inhibitor $(\mathrm{P}<0.05)$. No significant difference was observed between $C$. longa essential oil and the positive control.

After CAM image analysis, the membranes were submitted to histological analysis (Figure 3). The results showed an increase in the number of new blood vessels (neovascularization), inflammatory elements and hyperemia for CAMs submitted to C. longa latex and Regederm ${ }^{\circledR}$ when compared to the neutral control and inhibitor group $(\mathrm{P}<0.05)$. The literature reports that the inflammatory cells are important in activating factors to stimulate the angiogenic process (May et al. 2008). Inflammatory cells such as macrophages, lymphocytes, mast cells and fibroblasts are capable of stimulating vessel growth (Folkman and Brem 1992). Thus, angiogenesis and inflammation complement each other. Our histological data is in accordance with CAM images, which showed significant differences in the presence of inflammatory elements, hyperemia and neovascularization (Table I).

A number of plants and their different extracts have been investigated in relation to their angiogenic potential. Studies have demonstrated significant proangiogenic activity in the following species: Aloe vera (Atiba et al. 2011), Hippophae rhamnoids L (Gupta et al. 2008), Angelica sinensis (Meng et al. 2008), Cinnamomum cassia (Choi et al. 2009), Astragalus membranaceus (Zheng et al. 2011), Stewartia koreana (Lee et al. 2010), 
(a)
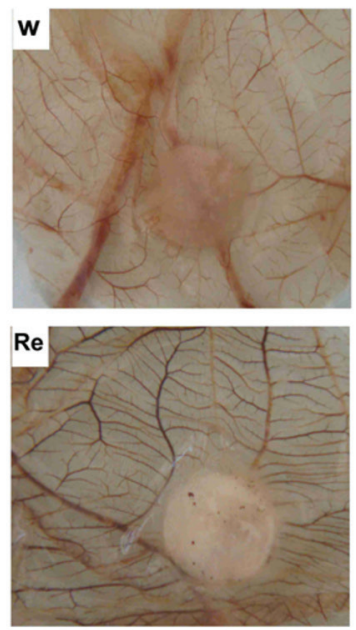
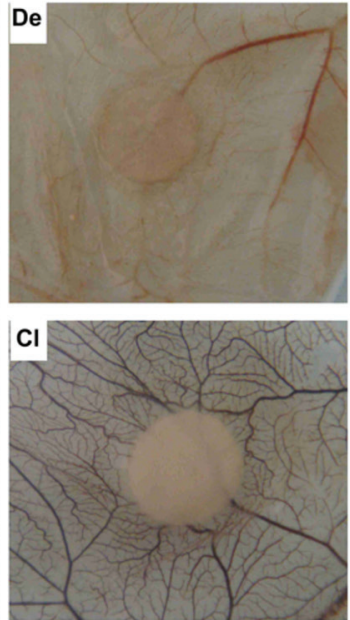

(b)

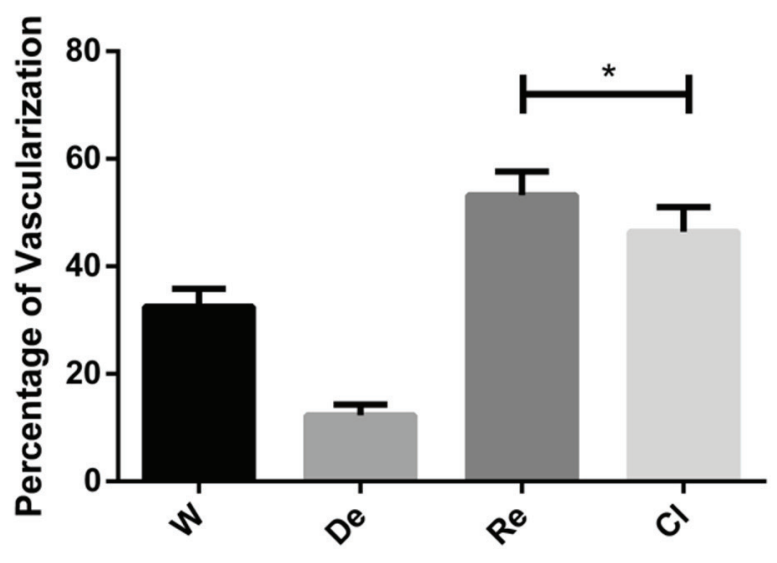

Figure 2 - (a) Vascular network in different controls in CAMs and (b) percentage of vascularization average by group: neutral control (distilled water, W); inhibitor control (dexamethasone, De); positive control (Regederm ${ }^{\circledR}, \mathrm{Re}$ ) and C. longa essencial oil $(\mathrm{Cl}) .{ }^{*}$ Groups without significant differences among themselves. The $C$. longa essential oil showed a significant increase in the vascular network formed, compared to the neutral control and the inhibitor $(\mathrm{P}<0.05)$, but between $C$. longa and positive control there was no significant difference $(\mathrm{P}>0.05)$.

TABLE I

Different histological parameters observed in CAMs submitted to different treatments.

\begin{tabular}{|c|c|c|c|}
\hline Groups & Neovascularization & Inflamatory elements & Hyperemia \\
\hline Neutral control (W) & Moderate $^{a}$ & Moderate $^{\mathrm{d}}$ & Discrete $^{g}$ \\
\hline Inhibitory control (De) & Discrete $^{b}$ & Absent $^{\mathrm{e}}$ & Absent $^{\mathrm{h}}$ \\
\hline Positive control (Re) & Accentuated $^{c}$ & Accentuated $^{\mathrm{f}}$ & Accentuated $^{\mathrm{i}}$ \\
\hline C. longa essential oil $(\mathrm{Cl})$ & Accentuated $^{c}$ & Accentuated $^{\mathrm{f}}$ & Accentuated $^{\mathrm{i}}$ \\
\hline
\end{tabular}

Same letters $(\mathrm{P}>0.05)$; Different letters $(\mathrm{P}<0.05)$.

All the results were compared to controls groups by Kruskal-Wallis one way ANOVA on ranks followed by multiple comparison procedure. $\mathrm{P}$ values less than 0.05 were considered as indicative of significance.

Uncaria rhynchophylla (Choi et al. 2005), Salvia miltiorrhyza (Lay et al. 2003), Patrinia vilosa (Jeon et al. 2010), Pueraria Montana (Chung et al. 2010), Panax notoginseng (Hong et al. 2009), Hancornia speciosa (Almeida et al. 2014), Hevea brasiliensis (Mrue et al. 2004).

As reported earlier, essential oil of C. longa consists of several compounds. To the best of our knowledge, there have been no reports evaluating the angiogenic activity of all essential oil compounds as a whole. However, the effect of C. longa isolated compounds has been widely studied. For example, there are different reports showing that curcumin exerts significant anti-inflammatory, antioxidant, anticarcinogenic, antimutagenic, anticoagulant and anti-infective effects (Maheshwari et al. 2006). Curcumin has also been shown to have significant wound healing properties, due to its ability to enhance granulation tissue formation, collagen deposition, tissue remodeling and wound contraction (Akbik et al. 2014).

Although many researchers have demonstrated that most pharmacological activities of C. longa are attributed to curcumin, this compound was found in low concentrations in C. longa essential oil. The results presented in this article show the 


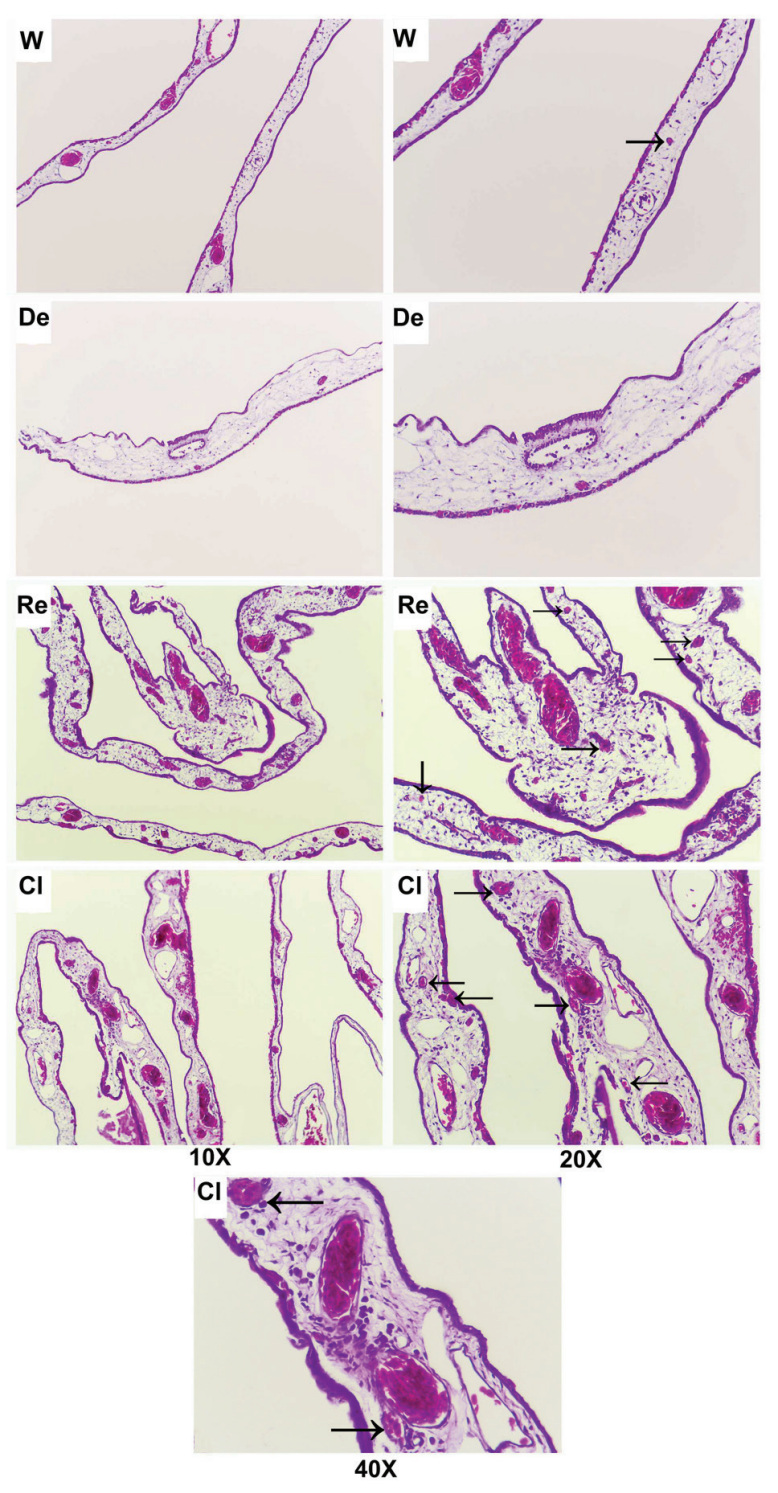

Figure 3 - Paraffin sections stained with hematoxylineosin with 10, 20 and 40x magnification. W: neutral control (distilled water); De: inhibitor control (dexamethasone); Re: positive control (Regederm $\left.{ }^{\circledR}\right)$; Cl: C. longa essencial oil (Cl). The arrows show neovascularization. Inflamatory elements are visualized as purple dots. Those elements were found more frequently in Re and $\mathrm{Cl}$. Hyperemia is identified by high erythrocytes concentration ( $\mathrm{Re}$ and $\mathrm{Cl})$.

angiogenic effect of C. longa essential oil, which could be due to activation of the inflammatory response of a specific phytoconstituent in synergy with curcumin. Other studies have shown that the synergic effect can be higher than the major compounds individually (Gill et al. 2002). This finding suggests that minority compounds may also be an important additive in the angiogenic process of C. longa essential oil.

\section{CONCLUSIONS}

The present study carried out photophysical and physicochemical characterization of $C$. longa essential oil as well as evaluating on its angiogenic potential. The results show that small amounts of curcumin are present in the essential oil and that the oil exhibits high thermal stability up to $90^{\circ} \mathrm{C}$. Furthermore, it was observed that curcumin is the main fluorescent component and that fluorescence emission can be attributed to the fluorescent resonance energy transfer (FRET) process. Essential oil showed considerable proangiogenic activity, which may be due to a synergic effect between its minor components. This result is an important indication that $C$. longa essential oil can be used as a compound to stimulate angiogenesis.

\section{RESUMO}

Neste estudo foram analisadas as propriedades físicoquímicas e fotofísicas do óleo essencial de Curcuma longa, bem como seu potencial angiogênico. Os resultados obtidos mostraram que a curcumina é o principal componente fluorescente, mas está presente em pequena quantidade no óleo essencial. $\mathrm{O}$ método experimental da membrana corioalantóide foi empregado para avaliar a atividade angiogênica do óleo e foi observado um aumento significativo na rede vascular nos grupos submetidos ao óleo de Curcuma longa e controle positivo, quando comparado com os grupos controle negativo e inibidor $(\mathrm{P}<0,05)$, mas não houve diferenças significativas entre o grupo tratado com óleo de Curcuma longa e o controle positivo ( $\mathrm{P}>0,05)$. A análise histológica mostrou maior neovascularização, hiperemia e elementos inflamatórios nos grupos controle positivo e Curcuma longa quando comparado aos demais grupos controles $(\mathrm{P}<0,05)$, fatores característicos do processo de angiogênese. Em conclusão, o óleo de Curcuma longa mostrou uma considerável atividade 
pró-angiogênica e pode ser um composto com potencial aplicações médicas.

Palavras-chave: atividade angiogênica, curcumina, óleo essencial, físico-química.

\section{REFERENCES}

AKBIK D, GHADIRI M, CHRZANOWSKI W AND ROHANIZADEH R. 2014. Curcumina as a wound healing agent. Life Sci 116:1-7.

ALMEIDA LM ET AL. 2014. J. Hancornia speciosa latex for biomedical applications: physical and chemical properties, biocompatibility assessment and angiogenic activity. J Mater Sci Mater Med 25: 2153-2162.

Anastasaki E, Kanakis C, Papas C, Maggi L, Del CAMPO CP, CARMONA M, ALONSO GL AND POLISSIOU MG. 2010. Differentiation of saffron from four countries by mid-infrared spectroscopy and multivariate analysis. Eur Food Res Technol 230: 571-577.

ARAÚJO CAC AND LEON LL. 2001. Biological activities of Curcuma longa L. Mem Inst Oswaldo Cruz 96: 723-728.

ATIBA A, Nishimura M, KAKINUMA S, HiRAOKA T, GORYO M, SHIMADA Y, UENO H AND UZUKA Y. 2011. Aloe vera oral administration accelerates acute radiationdelayed wound healing by stimulating transforming growth factor- $\beta$ and fibroblast growth factor production. Am J Surg 201: 809-818.

Chen W, LuA Y, GaOA M, WuA J, WANGa A AND ShiC R. 2011. Anti-angiogenesis effect of essential oil from Curcuma zedoaria in vitro and in vivo. J Ethnopharmacol 133: 220-233.

CHOI DY, BAEK YH, HUH JE, KO JM, WOO H, LEE JD AND PARK DS. 2009. Stimulatory effect of Cinnamomum cassia and cinnamic acid on angiogenesis through upregulation of VEGF and Flk-1/KDR expression. Int Immunopharmacol 9: 959-967.

CHOI DY, HUH JE, LEE JD, CHO EM, BAEK YH, YANG HR, CHO YJ, KIM KI, KIM DY AND PARK DS. 2005. Uncaria rhynchophylla induces angiogenesis in vitro and in vivo. Biol Pharm Bull 28: 2248-2252.

Chung BH, CHO YL, KIM JD, JO HS, WON MH, LEE H, HA KS, KWON YG AND KIM YM. 2010. Promotion of direct angiogenesis in vitro and in vivo by Puerariae flos extract via activation of MEK/ERK, PI3K/Akt/eNOS-, and Src/ FAK-dependent pathways. Phytother Res 24: 934-940.

EREZ Y, SIMKOVITCH R, SHOMER S, GEPSHTEIN R AND HUPPERT D. 2014. Effect of Acid on the UltravioletVisible Absorption and Emission Properties of Curcumin. J Phys Chem A 118: 872-884.

FERREIRA FD, KEMMELMEIER C, ARRotéIA CC, COSTA CL, Mallmann CA, JANEIRo V, FERreira FM, MOSSINI SA, SILVA EL AND MACHINSKI JR M . 2013.
Inhibitory effect of the essential oil of Curcuma longa L. and curcumin on aflatoxin production by Aspergillus flavus Link. Food Chem 136: 789-793.

FLORIANO JF, MOTA LS, FURTADO EL, ROSSETTO VJ AND GRAEFF CF. 2013. Biocompatibility studies of natural rubber latex from different tree clones and collection methods. J Mater Sci Mater Med 25: 461-470.

FOLKMAN J. 2003. Fundamental concepts of the angiogenic process. Curr Mol Med 3: 643-651.

FOLKMAN J AND BREM H. 1992. Angiogenesis and inflammation. In: Gallin JI, Goldstein IM and Snyderman $\mathrm{R}$ (Eds), Inflammation: basic principles and clinical correlates. 2nd ed., New York: Raven, 216 p.

GHosh M, SINGH ATK, XU W, SUlCHEK T, GORDON LI AND RYAN RO. 2011. Curcumin nanodisks: formulation and characterization. Nanomed Nanotechnol 7: 162-167.

Gill AO, Delaquis P, Russo P AND Holley RA. 2002. Evaluation of antilisterial action of cilantro oil on vacuum packed ham. Int J of Food Microbiol 73: 83-92.

GONÇALVES PJ, BAFFA-FILHO O AND GRAEFF CFO. 2006. Effects of hydrogen on the electronic properties of synthetic melanin. J Appl Phys 99: 104701-104705.

GUPTA A, UPADHYAY NK, SAWHNEY RC AND KUMAR R. 2008. A poly-herbal formulation accelerates normal and impaired diabetic wound healing. Wound Rep Regen 16: 784-790.

HONG SJ, WAN JB, ZHANG Y, HU G, LIN HC, SETO SW, KWAN YW, LIN ZX, WANG YT AND LEE SM. 2009. Angiogenic effect of saponin extract from Panax notoginseng on HUVECs in vitro and zebrafish in vivo. Phytother Res 23: 677-686.

IWU MM, JACKSON JE AND SCHUSTER BG. 1994. Medicinal plants in the fight against leishmaniasis. Parasitol Today 10: 65-68.

JEON J, LEE J, KIM C, AN Y AND CHOI C. 2010. Aqueous extract of the medicinal plant Patrinia villosa Juss. Induces angiogenesis via activation of focal adhesion kinase. Microvasc Res 80: 303-309.

JURENKA JS. 2009. Anti-inflamatory properties of curcumin, a major constituent of Curcuma longa: a review of preclinical and clinical research. Altern Med Rev 14: 141-153.

LAKOWICZ JR. 2006. Principles of Fluorescence Spectroscopy. 3rd ed., New York: Kluwer Academic/Plenum Publishers, $27 \mathrm{p}$.

LAY IS, CHIU JH, SHIAO MS, LUI WY AND WU CW. 2003. Crude extract of Salvia miltiorrhiza and salvianolic acid B enhance in vitro angiogenesis in murine SVR endothelial cell line. Planta Med 69: 26-32.

LEE TH, LEE GW, KIM CW, BANG MH, BAEK NI, KIM SH, CHUNG DK AND KIM J. 2010. Stewartia koreana extract stimulates proliferation and migration of human endothelial cells and induces neovasculization in vivo. Phytother Res 24: 20-25. 
MAHESHWARI RK, SINGH AK, GADDIPATI J AND SRIMAL RC. 2006. Multiple biological activities of curcumin: a short review. Life Sci 78: 2081-2087.

MAJEWSKA I AND GENDASZEWSKA-DARMACH E. 2011. Proangiogenic activity of plant extracts in accelerating wound healing - a new face of old phytomedicines. Acta Bioch Pol 58: 449-460.

MATA AR, NELSON DL, AFOnso RJCF, GLÓRIA MBA AND JUNQUEIRA RG. 2004. Identificação de compostos voláteis da cúrcuma empregando microextração por fase sólida e cromatografia gasosa acoplada à espectrometria de massas. Ciênc Tecnol Aliment 24: 151-157.

MAY AE, SEIZER P AND GAWAZ M. 2008. Platelets: inflammatory firebugs of vascular walls. Arterioscler Thromb Vasc Biol 28: 5-10.

Melo-Reis PR, ANDRAde LS, Silva CB, ARAÚJo LMM, Pereira MS, Mrue F AND CHEN-Chen L. 2010. Angiogenic activity of Synadenium umbellatum Pax látex. Braz J Biol 70: 189-194.

Meng H, GuO J, SUN JY, PEI JM, WANG YM, ZHU MZ AND HUANG C. 2008. Angiogenic effects of the extracts from Chinese herbs: Angelica and Chuanxiong. Am J Chin Med 36: 541-554.

MOHANTY C AND SAHOO SK. 2010. The in vitro stability and in vivo pharmacokinetics of curcumin prepared as an aqueous nanoparticulate formulation. Biomaterials 31 : 6597-6611.

Mostajeran A, GHolaminejad A AND Asghari G. 2014. Salinity alters curcumin, essential oil and chlorophyll of turmeric (Curcuma longa L.) Res Pharm Sci 9: 49-57.

Mrue F, NetTo JC, Ceneviva R, LACHAT JJ, ThOMANIZI JA AND TAMBELINI H. 2004. Evaluation of the biocompatibility of a new biomembrane. Mate Res 7: 277283.

NASRI H, SAHINFARD N, RAFIEIAN M, RAFIEIAN S, SHIRZAD M AND RAFIEIAN-KOPAEI M. 2014. Turmeric: A spice with multifunctional medicinal properties. J Herbmed Pharmacol 3: 5-8.

ORDOUdI SA, PASCUAL MM AND TSIMIDOU MZ. 2014. On the quality control of traded saffron by means of transmission Fourier-transform mid-infrared (FT-MIR) spectroscopy and chemometrics. Food Chemistry 1: 414-421.

PARENTE LML, ANDRADE MA, BRITO LAB, MOURA VMBD, MIGUEL MP, LINO-JÚNIOR RS, TRESVENZOL LFM, Paula JR AND Paulo NM. 2011. Angiogenic activity of Calendula officinalis flowers L. in rats. Acta Cir Bras 26: 19-25.

PÉret-Almeida L, NAGHetini CC, NunAN EA, JUNQUEIRA RG AND GLÓRIA MBA. 2008. Atividade antimicrobiana in vitro do rizoma em pó, dos pigmentos curcuminóides e dos óleos essenciais da Curcuma longa L. Ciênc Agrotec 32: 875-881.

PHILLIPSON JD. 1994. Natural products as drugs. Trans R Soc Trop Med Hyg 88: 17-19.

RiBATTI R, VACCA A, RONCALI L AND DAMMACCO F. 2000. The Chick Embryo Chorioallantoic Membrane as a Model for in vivo Research on Anti-Angiogenesis. Curr Pharm Biotechnol 1: 73-82.

Rodrigues SE, MACHADO AEH, BERARDi M, ITO AS, ALMEIDA LM, SANTANA MJ, LiaO LM, BARBOSANETO NM AND GONÇALVES PJ. 2015. Investigation of protonation effects on the electronic and structural properties of halogenated sulfonated porphyrins. J Mol Struc 1084: 284-293.

SAMPAIO RN ET AL. 2012. Investigation of Ground- and Excited-State Photophysical Properties of 5,10,15,20-Tetra(4-pyridyl)-21H,23H-porphyrin with Ruthenium Outlying Complexes. J Phys Chem 116: 18-26.

SAntos AS, Alves SM, Figueredo FJC AND Neto OGR. 2004. Descrição de sistema e de métodos de extração de óleos essenciais e determinação de umidade de biomassa em laboratório. Ministério da Agricultura, Pecuária e Abastecimento- Comunicado Técnico 99: 1-6.

Schultz GS, SibBad RG, FAlanga V, Ayello EA, DOWSETT C, HARDING K, ROMANELLI M, STACEY MC, TEOT L AND VANSCHEIDT W. 2003. Wound bed preparation: a systematic approach to wound management. Wound Repair Regen 1: S1-28.

SHAMEli K, AHMAD MB, SHABANZADEH P, JAFFAR EA AND ZAMANIAN A. 2014. Effect of Curcuma longa tuber powder extract on size of silver nanoparticles prepared by green method. Res Chem Intermed 40: 1313-1325.

SHEN JT AND FALANGA V. 2003. Innovative therapies in wound healing. J Cutan Med Surg 7: 217-224.

SRIMAL RC. 1997. Turmeric: a brief review of medicinal properties. Fitoterapia 68: 483-493.

ZHENG KY ET AL. 2011. Flavonoids from Radix Astragali induce the expression of erythropoietin in cultured cells: a signaling mediated via the accumulation of hypoxiainducible factor-1 $\alpha$. J Agric Food Chem 59: 1607- 1704. 